\title{
Follow the money
}

\section{Borders no longer constrain the flow of capital, ideas and talent to emerging centres of excellence.}

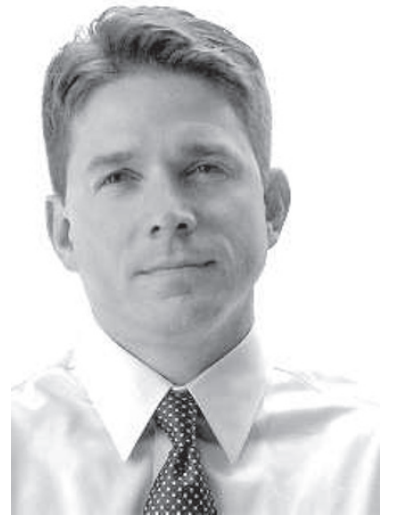

Michael Alvarez

Global economics is changing and science is changing along with it - a trend that has implications for everyone from students to industry researchers to policy-makers in federal and local government. The convergence of communications and computing advances has brought new players into the global marketplace. As a result, competition for both talent and market share is intensifying, and the field has been levelled.

This levelling effect poses a challenge for traditional science and technology companies and the regions that host them. They need innovators and talented employees in order to stay competitive.

It also creates job opportunities in the emerging centres. As the field of players grows more crowded and diverse, there are greater opportunities for new countries, institutions and individuals to emerge as leading producers of cutting-edge innovations. A growing middle class in developing countries, including well-educated and technically skilled people, means that there is a greater base of individuals both generating and circulating money for their local economies.

The competitive advantage belongs to those companies, regions and countries most capable of transforming technologies into commercial products. These innovations provide them with both trade

\section{TURNING IDEAS INTO INCOME}

\section{Biotech publication rankings \\ 1. Harvard University \\ 2. University of Tokyo \\ 3. University of London \\ 4. University of California, San Francisco}

\section{Biotech patent ranking \\ 1. University of Texas \\ 2. University of California, San Francisco}

3. Johns Hopkins University

4. Stanford University

Technology-transfer and commercialization index

1. Massachusetts Institute of Technology

2. University of California

3. California Institute of

Technology

4. Stanford University Source: Milken Institute, 2000-04 opportunities and sustainable employment. The transformation requires capital, infrastructure, ground-breaking technology and a high-quality workforce.

The quest for technologies and talents is less bounded by geography than in the past. The capital, technology and skilled professionals needed to drive

"Regions seeking to

become 'the' hub of any innovation need talented individuals to help them attract investment."

economic growth today can be gathered from numerous locations, and companies are increasingly able to attract the resources they need from distant corners of the globe. Note, for example, that the four leading institutions in terms of biotech publication rankings are located in three different countries (see 'Turning ideas into income').

Competition is keen among regions, both within countries and internationally, to become known as 'the' international hub for selected high-technology sectors. It's not just India and China - European cities and non-traditional research locales in the United States, from Ohio to Florida, are competing for talent and funds. They position themselves as being hospitable to business, by providing inducements such as capital, access to markets, favourable regulatory environments and, of course, a highly skilled technical workforce.

One prime example is embryonic stem-cell research. The United States' restrictive federal policy has held it back while countries such as Australia, the United Kingdom and Singapore (and some US states, mostly notably California) aim to become hubs for a field that is still in its infancy. Across many areas of science and technology, new players have emerged to compete with traditional centres. From Bangalore to Berlin and Shanghai to San Diego, more and more cities are aiming to become leaders in promising high-technology sectors.

So how can one identify regions that actually have what it takes to succeed in this global marketplace, where the opportunities for sustainable profits, employment and technological development are greatest?

Although computing and telecommunications technologies have played down the importance of geographical location, it is crucial for companies to be located close to universities and to collaborate with them.

Universities play a leading role in generating early-stage technologies and producing skilled trainees. They also patent and license technologies for commercial development. This means that investors and researchers from across the globe can be on the spot to engage with the technological advancements and people most relevant to their own objectives and interests.

The onus is also on industry and government to provide policies, infrastructure and funds to translate ideas and discoveries into products. Their moves in this regard may very well determine the success or failure of science and technology hubs.

The regions that will earn a place at the front of the pack are those most capable of adapting to the new playing field, operating effectively within a distributed work environment and developing relationships across borders to source the best talents and technologies. Skilled individuals who are flexible and mobile enough to take advantage of the regions' needs have a good chance of reaping the rewards. Michael Alvarez is director of Stanford University's School of Medicine Career Center, California. 